\title{
Discussing Islamic Fundamentalism and Its Role in Politicizing Religion
}

\author{
Hani Ahmed Shboul \\ Al-Balqa Applied University, AlSalt, Jordan \\ Email: hani0789@bau.edu.jo
}

How to cite this paper: Shboul, H. A. (2020). Discussing Islamic Fundamentalism and Its Role in Politicizing Religion. Open Journal of Political Science, 10, 626-637. https://doi.org/10.4236/ojps.2020.104037

Received: July 27,2020

Accepted: August 23, 2020

Published: August 26, 2020

Copyright $\odot 2020$ by author(s) and Scientific Research Publishing Inc. This work is licensed under the Creative Commons Attribution International License (CC BY 4.0).

http://creativecommons.org/licenses/by/4.0/

(c) (i) Open Access

\begin{abstract}
One of the meanings of Fundamentalism means literal adherence to religious texts, closure in the past, and contempt for the present and the future together. This is because fundamentalists always look back, not forward. They are fixed to a specific moment in the past, a moment that transcends all moments! Islamic fundamentalism, as explained in the Literatures of fundamentalist groups themselves, is an idea based on adhering to the fundamentals of religion and returning to the beginnings, as was the case during the era of the Prophet and his companions. The central theme of this article is to gain a deeper understanding, and wider discussion of Islamic Fundamentalism; a phenomenon whose destructive effects have reached the four corners of the world. The danger that Islamic fundamentalism poses is that it is the main supplier of ideas to jihadist militias who have carried out most of the terrorist acts in the world. The article, also, tried hard to explore the type of relationship between religion and politics in Islamic fundamentalist thought.
\end{abstract}

\section{Keywords}

Ministry, Islam, Political, Fundamentalism, Criticism

\section{Introduction}

When we hear the word fundamentalism, we immediately remember those intransigent religious groups that return everything to origins and beginnings, and offer interpretations and visions of contemporary issues based on past intellectual and moral foundations.

Religious fundamentalism refers to the belief of an individual or a group of individuals in the absolute authority of a sacred religious text or teachings of a particular religious leader, prophet, and/or God. These fundamentalists believe that their religion is beyond any form of criticism, and should therefore also be 
forced upon others. Logical explanations and scientific evidences have no place in these belief systems if they work against their religious fundamentalism. For fundamentalists, religion dictates every sphere of their daily lives, and they also attempt to involve the entire society into their own belief system, often by the use of force (Sen Nag, 2017).

Let us begin by looking at the root of the word, what does "fundamentalism" and "fundamentalist" mean in Arabic? Fundamentalism in language is taken from the verb "origin" of the thing. The origin of the thing: the basis on which it is based. This is not the concept of fundamentalism in Arabic alone, but in other languages. This means that fundamentalism in all languages means a return to the origin (Hussein, n.d.).

The concept is not limited to the Arabic language. When evangelical Americans attempted to reinterpret the Gospel literally, they were called fundamentalists. The same term was used with Jews such as Menachem Schneerson-Hassidi and his followers in New York and Jerusalem, when they apply the Torah literally. So fundamentalism is not confined to Islam (Hoffman, 1997).

The German Foreign Ministry defined "fundamentalism", at its conference on 22 January 1987, as a movement that complied with the norms, values and methods of practicing fundamentalist Islam when it emerged as a model for the formation of the present. It is a method of seeing and dealing with the world (Hoffman, 1997).

Historically, Arabic does not know the term fundamentalism, nor has it described any of the religious sects or groups that have adhered to religion strictly as fundamentalist. The significance of the concept of fundamentalism, as we know it today, was not formed in the Arabic language until very soon. It only appeared in the last three decades of the last century. This term is not the birth of the Arab Islamic environment, it first appeared in the West and in its languages, and then transferred to the Arabic language (Glend, 1999).

So fundamentalism is defined in the most known languages, and it means a return to the origin. What is important to us is to know the connotations and meanings of this term in Islamic fundamentalist thought, and to know how it emerged and was able to emerge in this form that it is today. It has become synonymous with extremism and violence. The term "fundamentalism" is also used in Arab and Western political discourse to refer to a form of religious extremism, usually "Orthodox", or "ultra-Orthodox" (Al-Jasur, 2004).

Islamic fundamentalism, then, means a return to the early origins of Islam and the attempt to apply it literally by resorting to the references of those origins and following the example of the early Muslims ( $\mathrm{Al} \mathrm{Salaf)}$ and their rulings. It opposes all forms of rational interpretations that attempt to adapt the divine text to the present time and place (Hero, 1997).

The concept of fundamentalism now has a political and intellectual connotation linked to a set of negatives, especially after the emergence of radical political groups and trends that carry Islamic slogans in the form of political programs 
and their excessive use of violence, terrorism, wars, chaos and unrest.

Many Islamic terrorist organizations, such as al-Qaeda, Boko Haram, and ISIS, also hold fundamentalist attitudes, and regard Western civilization as the symbol of the secular modernization that is a threat to the traditional Islamic values (Sen Nag, 2017).

Islamic fundamentalism emerged in two periods of the history; the first was during Abbasid period: when Imam Ahmad ibn Hanbal emerged, followed by his students such as Ibn Taymiyyah and Ibn Qayyim al-Jawziyyah, and then Muhammad ibn Abd al-Wahhab, who solidified adherence to the origins of Islam and rejecting of the new. The second is contemporary, it's the period of establishment of Muslim Brotherhood movement in Egypt; the emergence of Abu Alaa al-Mawdudi in Pakistan, and the jurisprudence of Sayyid Qutb. This second period is considered to be a renewal of the first period.

\section{Sources of Islamic Fundamentalism}

Muslim fundamentalist (groups, individuals and preachers) who see Islam as a religion and temporal and want to practice politics and manage the walks of life of people according to sharia, are based on two primary sources, namely the Quran and Sunna. All the literature of these groups and their scholars recognize Quran and Sunna as the main sources of legislation, morals, values, visions and perceptions. No human law can violate or contradicts what is stated in the Quran and Sunna. In their view, the right Islamic community should establish itself, in public and private life, on the basis of the Quran, which must be its guide to all matters of great or minor affairs of its life (Arkoun, 1996).

According to the fundamentalist view, it is not permissible to lax in relying on the Quran and Sunna over the ages. They are fixed references, in which time does not affect or diminish their values. Development can not eliminate dependence on the basic references of Islam (Al-Qaradawi, 1998). Muslims at the dawn of Islam, in the time of Muhammad and the era of the Caliphs and the Companions, the fundamentalists argue, Quran was the only lexicon in their lives, and the Prophet was their reference for the duration of his life, then, after his death, the hadiths of the Prophet were their reference in their public and private affairs (Eamara, 1994).

Muslim fundamentalists consider their book a miracle that cannot be achieved. They challenged the world through the ages by presenting a book similar to it in its communion and its coverage of matters of religion and the world. They believe that every rule derived from its verses is a valid judgment that cannot be rejected. The Quran is an eternal miracle, including the natural sciences, knowledge, human sciences and guidance that humanity needs. This miracle will remain young, eternal, and stronger as time progresses, and the human mind advances (Eamara, 1994; Wahba, 1995).

(Mufti, 1996) considered Quran as the first source of laws, and moral values that governing life, which no Muslim should violate. They also created theories 
about all branches of life-political, economic, social and philosophical-based on Quranic verses, and relying on the interpretations of early fundamentalist such as Ibn Taymiyyah, Muhammad ibn Abd al-Wahhab and later like Abu Alaa al-Mawdudi and Sayyid Qutb.

For them, Quran is the source of absolute divine truth that must be followed strictly and literally, without regard to time and places (Haider, 1997). This Quran is also the only true "divine document", while other sacred books have been distorted and have no truth, such as the Book of Muslims. It is the only divine document that has not been distorted or altered (Al-Badawi, 2002).

Muslim's fundamentalist thought depends on the text of the Quran, and its literal application to all aspects of life, anywhere and anytime. The sacred text is in itself sufficient for the fundamentalists as a source of life's meaning and purpose. The textual narrative provides fundamentalists with a worldview that allows comprehensibility and manageability to an otherwise fragmented existence [...] Textual authority, for fundamentalists, provides moral certainty and stability (Marranci, 2009: p. 29).

Their mind relies on the Quranic text and rejects any written text of human beings, no matter how this text embodies the living reality of this time. Interpretation of the Quran is fixed and must be applied, and humans have no right to discuss its validity.

The second reference to Islamic fundamentalist groups is the Sunna: The Sunna is the hadiths that have frequently been narrated from Prophet Muhammad and transmitted by his companions, and included some aspects of religion and life, which did not specify in the first reference: the Quran.

When they did not find in the Quranic verses a "support" for making a position on a particular issue, the fundamentalists resort to the Prophetic Sunna (Hadith) as a sacred second pillar of Islam (Jaafar \& Ahmed, 1995). Their definition of the Sunna is all that was issued by the Prophet Muhammad, other than the verses of the Quran, from words, deeds or reports. Therefore, adhering to the Sunna is a religious obligation (Mahmoud, 1999).

\section{Criticism of Fundamentalist Discourse}

Criticism continues against the fundamentalists' interpretation of the texts of the Islamic religion, and their claims of its validity to the current era, and then turn it into a project for the conduct of all affairs of life, without taking into account the contemporary life as a whole that has changed. What distinguishes fundamentalist discourse in particular is that, despite the nature of the crises it is dismantling, its solutions are a set of fixed formulas inspired by the distant past, not only as a valuable reference but as a verifiable project for the future as well (Eamara, 1994).

The social and political model achieved in the first Islamic era, in the view of fundamentalist groups, is not only the ideal model but also the only possible path to overcome the difficulties and achieve the desired goals at all levels (Bin 
Abd Al-Allawi, 1998).

By following the march of Islamic fundamentalist groups, we find that they do not adhere to the fundamentalist applications of Islam based on faith and belief only as they always promote, but it is also driven by a purely political drive aimed at winning the hearts and emotions of the Muslim public and to exploit this passion in order to pass its political discourse and achieve its mundane goals.

Islamic fundamentalist movements present themselves as the guardian of religion and sharia through their attachment to the fundamentals in order to market their discourse to the people (Ashmawy, 1996). Thus, the contemporary fundamentalist discourse, although well aware today that the norms and consensual forms that organized the collective and political life of simple nomadic communities living on grazing, invasion and the caravan trade, can in no way respond to the needs of contemporary societies. Nevertheless, they remain clinging to the ancestral basis of understanding Islam, because, on one hand, and from the position of opposition to existing political systems, they need a populist rhetoric full of symbols capable of fomenting emotions rather than realistic solutions. On the other hand, they aspire to acquire the appearance of the defender of historical identity, given the rich national and religious glories of the past, and remarkable personalities, whose paths are re-read in the light of contemporary needs, so that these glories and personalities become a pure investment of the fundamentalist speech (Shafai, 1999).

Therefore, we see that Islamic fundamentalist groups consider fundamentalism as a fundamental and legitimate source of their ideology. There is "legitimate" evidence presented by Ibn Taymiyyah, Ibn Qayyim al-Jawziyya and alMawdudi on the necessity of adhering to the Sharia, as evolved in medieval ages, in the conduct of political life in Muslim countries (Haider, 1998).

For fundamentalist, Islam is not only a religion; it is a social, political and economic system, and it is a civilization that applies to all times, places and countries (Hero, 1997).

They continue to explore competing political concepts and theories about Islam as the foundation of government and authority, or even the sole source of legitimacy and authority in a society (Stimson.org, 2016). Marranci has notably pointed out that, "fundamentalism is a protest and an opposition toward any form of power that is not guided by a divine scripture" (Marranci, 2009: p. 53).

Muslim Brotherhood, the largest Islamic fundamentalist movement in the Islamic world, has announced its ideas: Islam is a comprehensive system that automatically develops itself, and the basic way of life in all its different fields, emanates and is based on two main sources, the Quran and Sunna, and is applicable to all times and places (Zaki, n.d.). In short, they emphasize that; Islam is a comprehensive ideology that offers a system that is fully capable of organizing all the details of political, economic, social and cultural life of believers. Its founder Hassan al-Banna described the Muslim Brotherhood as a Salafist message, a 
Sunni way, a political organization, a sports group, a scientific society, an economic project and a social idea (Zaki, n.d.; Hero, 1997).

In its efforts to implement its programs, fundamentalist Islamic groups have tried to rule out other jurisprudence that might hinder their political plans. They considered that their opposition to governments that do not enforce Sharia is permissible. It resorts to strict interpretation of religious texts, and recalling Islamic history and its events, so that their resistance of communities and governments become legitimate jihad for the sake of God (Dkmjian, 1989).

There is a thoughtful evocation of the Islamic history to judge the present and the future. The problem of the fundamentalists revolves around the fact that they want to transform what is historical into logical, in the sense that they have a firm belief that Islam provides humanity with answers to all important questions of worldly affairs, regardless of historical conditions. Fundamentalists Muslims rejected secularism not only from religious angle but also from the cognitive point of view (Wahba, 1995).

The reliance on religious fundamentalism makes individuals and groups reject the principles of modern human civilization represented by civil, rationality, rule of law, principles of human rights and public freedoms.

The rights of individuals and their personal and public freedoms are not one of the priorities of fundamentalist Islamic groups, their priority is to achieve a religious state and strictly apply the provisions of Islamic law, disregarding the contrast between present and past, developments in social, economic and cultural levels and changes in international relations (Moadab, 2002). The researcher in the affairs of Islamic fundamentalist groups finds the same "constant" that their only demand is to affirm religious character of state and society and to apply the provisions of Sharia. The liberation of man and the question of development, which the Muslim peoples desperately need, have no regard for the fundamentalists (Ismail, 1993).

Islamists political groups rejected the introduction of a democratic civil state, in the Western sense. They made Islamic original sources references for their political ideology. This is the philosophy of Islamic fundamentalism since the birth of Muslim Brotherhood in Egypt until today. Hassan al-Turabi, a Muslim brotherhood leader, does not hesitate to say that the application of Sharia is one of the manifestations of true independence. The application of Sharia makes us emerge from the "vicious circle of poverty, indebtedness and economic impotence" (Al-Sharafi, 2008: pp. 23, 40).

(Qutb, 1979) considered that the trends of philosophy as a whole, the trends of psychology in its entirety and all the branches of social science are ignorant sciences, forbidden to Muslims, that is, non-Islamic. He viewed every form of Western heritage and culture as necessarily antithetical to Islam. Therefore, all that is not Islamic should be renounced, because it is ignorant culture against Islamic culture. Hence, the concept that culture is a human heritage, with no homeland, no race, no religion, is a true concept, but not for the fundamentalists. 
Although political Islamic groups claim to want political participation and run for elections, the truth is that the fundamentalist interpretation of Islam has driven most of them to take up arms and resort to violence to achieve their political agenda. Although this method has achieved nothing but shedding the blood of innocent people, it's still present and is a clear choice for many Islamic groups (Group of Authors, 1990: p. 12).

Political terrorism that carried out by fundamentalist, whose aim is to overthrow the existing political systems by armed force, is the result of their rejection of civil state. Terrorism appeared when the followers of fundamentalism came out of the realm of thought and belief, into the arena of action to apply fundamentalist ideas by force (Al-Sharafi, 2008: pp. 40, 41).

Fundamentalists have made the religious text a legal basis for their terrorist operations. They have not come from a vacuum: they have satiated since their youth with a hostile ideology that has been planted in the consciousness of Muslim societies for hundreds of years and you cannot come today and disavow them and call them terrorists and killers (Saleh, 2006: p. 121).

Most of the world's 1.6 billion Muslims do not countenance violence and human rights violations, but the fact remains that fundamentalists are not a fringe group; they occupy senior positions in Muslim clerical hierarchy. There are tens of millions (or more) of them, and they believe their interpretation of Islam is the only correct one (Tavakoli, 2017).

Fundamentalist logic reject civil laws and regard them as the work of human beings, not sanctified in front of the binding legal texts revealed by God. For them, Islamic sharia is always the one that presents all the solutions to all the problems posed (Qutb, 1991).

Some of the critical opinions, which subjected the sacred religious text to contemporary scientific standards in the sciences of language and interpretation, concluded that these texts are the basis of their time and place and cannot be separated from the temporal and spatial environment in which they were presented, they carried a message concerning certain incidents (Luhaiq, 1992). The divine source of these texts does not completely negate the fact that they are linguistic texts, and is associated with time, historical and social place (Hamed Abu Zayd, 1995: p. 62).

Thus, as long as the divine text appears in a human language to address human beings, it will be subject to study and rationalization by human beings. This does not prevent the sanctity of the religious text (Hamed Abu Zayd, 1995: p. 63). The Quranic text is the most sacred text in the Arabic language. Some scholars even consider that Arab-Islamic civilization was a civilization of the text, meaning that the text of the Quran had a central role in it. This does not mean that the text alone created civilization, the text, whatever it is, does not create civilization or establish science and culture. The one who created civilization is the argument of man with reality on one hand and his dialogue with the text on the other (Ibriz, 2007: p. 34). 
The Quranic text has been at the forefront of Arabic language and civilization, and for centuries it has been indisputable (Yassin, 1996). Modern views demanding the submission of this text to scientific research or rationality. Fundamentalist refuse to remove the status of holiness and divinity from the Quranic text and consider it a human text that can be interpreted and explained.

There are differences over interpretation of the religious text on the cultural and intellectual level. There are divergent views in regard to this text as a reference to which domestic and international political matters are measured. Some believe that the text should be interpreted according to the time or place in which it will be applied, meaning that the interpretation is changeable. While others (the fundamentalists) see it as an eternal text (in its origin) that is suitable for all times and places, and its application on the ground in a literal manner is a religious duty. The fundamentalists consider the text always valid, and it is not permissible to delve into its validity at any time or in any place (Group of Researchers, 2005: pp. 52-53).

The advocates of the opinion that inclined to linguistic and historical interpretation of the religious text of Islam argue that this text has been greatly influenced by the environment in which it appeared. It appeared in a form appropriate to the people that address them. Therefore, its interpretation in a literal and restrictive manner, without taking into account the time, place, and social, political, economic and value changes, is an erroneous, unscientific, but primarily ideological and political interpretation aimed at achieving purely worldly goals (Hamed Abu Zaid, 1990: p. 17).

(Abdul Karim, 1995) view that applying the religious text literally as far away as the time of Prophet Muhammad and his companions are illogical and incompatible with the sense of human mind and the nature of present life, because at that stage the prevailing conditions were different from the current circumstances. The religious text was an explanation of the political and social events of the time, and it was an incidental text, in the sense that it appeared on occasions related to the situation of Muslims of that era. Insisting on the application of sharia, and its validity for contemporary time is a coup against reality.

TheQuranic text is based on implication and indirect inspiration. It uses metaphor, images, proverbs, references and hints, and does not address the minds of Muslims openly and directly. This opens the door for interpretations, Therefore, the constitutive text theoretically corresponds to an unlimited number of interpretations (Group of Authors, 1990: p. 12).

While the modernists reject the application of sharia literally or based on old interpretation of the texts, because these texts are the basis of their time and place, they demand that they be subject to study and investigation according to modern scientific methods. The fundamentalists oppose this view and accuse the modernists, who are trying to apply modern Western sciences to the divine Quranic text, of being infidels (Rustam, 2011).

What the fundamentalists have done is that they have removed the Quran and 
the Sunna from their historical context and penetrated them into contemporary life, and considered them divine texts. Therefore, believers are obligated to accept these texts as they are, not to subject them to contemporary cognitive tools. This means that God has issued texts above the understanding of human beings and obliged them to accept them as they are without understanding or diligence. This insistence necessitates Divine Providence interferes to enable believers understand them, otherwise religious texts become texts above ordinary human understanding (Hamed Abu Zaid, 1994: p. 206).

(Shboul, 2018) explained that, although, adhering to the religious texts literally, yet the texts need, in the final analysis, human understanding and interpretation to disclose their meanings and significance. According to the religious discourse, presented by fundamentalists Muslims, the only authority capable of carrying out this task with absolute objectivity, is the authority of the clergy, (Council of Muslim Ulama, Department of Ifta or self-appointed Ulama or muftis ...) that is, the rule of God (Allah), actually, turns into the rule of the clergy. In the end, they are human beings, with their biases and ideological illusions.

Adherence to Religious texts, which monopolizes the truth, without reform and a new understanding, led to extremism, fanaticism, intolerance and terrorism.

\section{Conclusion}

As the above study shows, the doctrine of fundamentalist Islam is totalitarian, closed, and cannot accept other interpretations, and is based on a set of non-negotiable arguments. Fundamentalists thinking is limited within religious texts and has nothing to do with reality. Their certainty is a subjective certainty, not based on factual evidence. There is no room for discussion and demonstration, as the truth is absolute and monopolized exclusively by them.

Politically, fundamentalism does not provide a clear paradigm. Their political ideas are blurry and vague. For example, the currents "Islamic fundamentalism" do not have a clear political system. Their thought is not subject to development and change. Development of thought requires the application of critical philosophical approaches, but "fundamentalists" disbelieve in philosophy. Facts, in the view of fundamentalists, are only the sacred facts, not subject to criticism and analysis. They also reject the present and the contemporary and wish to return to the past.

Despite the efforts of governments and civic organizations to combat fundamentalist thought. However, there are dimensions that hinder these efforts, the most important of which, in view of the researcher, is the social and cultural dimensions that are still compatible, in most of Islamic societies, with fundamentalist discourse. The reason for this is the lack of an alternative religious discourse.

In addition, educational systems in many Muslim countries lack methods of criticism and scientific thinking. When education turns to be based on critical 
science, rationality, and human logic, this phenomenon will disappear.

\section{Funding}

The author received no financial support for the research, authorship, and/or publication of this article.

\section{Conflicts of Interest}

The author declares no conflicts of interest regarding the publication of this paper.

\section{References}

Abdul Karim, K. (1995). Islam between the Religious State and the Civil State (p. 72). Cairo: Sina Publishing House.

Al-Badawi, J. (2002). The Green Sword: A Study in Contemporary Islamic Fundamentalism (pp. 21 and 22). Cairo: Dar Qaba for Printing and Publishing.

Al-Jasur, N. M. (2004). Encyclopedia of Political Science (p. 64). Amman: Majdalawi Printing and Publishing House.

Al-Qaradawi, Y. (1998). Sharia Politics in the Light of Sharia and Its Purposes (p. 17). Cairo: Wahba Library.

Al-Sharafi, M. (2008). Islam and Freedom: Historical Misunderstanding (pp. 23 and 40). Damascus: Petra Publishing and Distribution.

Arkoun, M. (1996). Islamic Thought: Scientific Reading (Translated by Hashem Saleh, 2nd ed., p. 145). Beirut: Arab Development Center.

Ashmawy, M. S. (1996). The Essence of Islam (4th ed., p. 48). Cairo: Madbouly Al-Saghir Library.

Bin Abd Al-Allawi, M. (1998). Contemporary Islam: Reading in the Letter of Rooting (p. 29). Damascus: Dar Mad for Printing and Publishing.

Dkmjian, R. H. (1989). Fundamentalism in the Arab World, Translation: Abdel-Wareth Said (p. 79). Cairo: Dar Al-Wafaa for Printing and Publishing.

Eamara, M. (1994). Salafism (p. 51). Sousse: Dar Al-Maarif for Printing and Publishing.

Glend, M. El-S. (1999). Fundamentalism and Dialogue with the Other (p. 10). Cairo: Dar Qabaa for Printing and Publishing.

Group of Authors (1990). Reading a Religious Text (2nd ed., p. 12). Tunis: The Tunisian Publishing House.

Group of Researchers (2005). The Religious Text and Its Function, Round Table Work Held in Cooperation between the Institute of Islamic and Christian Studies at Saint Joseph University and the Institute of Judicial Knowledge for Religious and Philosophical Studies (p. 47). Beirut: Dar Al-Shorouk.

Haider, K. (1997). The Political Development of the State of Islamic Movements (pp. 1 and 2). Abu Dhabi: Emirates Center for Strategic Studies and Research.

Haider, K. A. (1998). Moderation or Extremism: Critical Reflections on the Islamic Moderation Movement (p. 56). Kuwait: Qurtas Publishing House.

Hamed Abu Zaid, N. (1990). The Concept of the Text: A Study in the Sciences of the Qur'an (p. 17). Cairo: The General Kurdish Book Authority.

Hamed Abu Zaid, N. (1994). Criticism of Religious Discourse (2nd ed., p. 206). Cairo: 
Sina Publishing House.

Hamed Abu Zayd, N. (1995). Text, Authority, Truth: Religious Thought between the Will to Know and the Will to Dominate (p. 92). Casablanca: Arab Cultural Center.

Hero, L. (1997). Islamic Fundamentalism in the Modern Age, Translated by Abdel Hamid Fahmy Al-Gammal (p. 14). Cairo: Egyptian Book Authority.

Hoffman, M. (1997). Islam as an Alternative, Translated by Adel Al-Muallem (pp. 67 and 68). Cairo: Dar Al-Shorouk.

Hussein, I. A. S. (n.d.). Fundamentalism and Other Fundamentalisms (p. 21). Beirut: Dar Al-Kutub Al-Alamia.

Ibriz, B. (2007). The Concept of Text in the Linguistic Arab Heritage. Journal of Damascus University, Damascus, Syria, First Issue, 23, 34.

Ismail, M. (1993). Political Islam between Fundamentalists and Secularists (p. 96). Kuwait: The Arab Sail Foundation.

Jaafar, A., \& Ahmed, H. (1995). The Political Dimensions of the Concept of Governance: A Cognitive Vision (p. 89). Virginia: International Institute of Islamic Thought.

Luhaiq, A. al-R. b. M. (1992). Exaggeration in Religion in the Contemporary Life of Muslims (2nd ed., p. 44). Beirut: Al-Risala Foundation.

Mahmoud, I. (1999). The Holy Fitna: The Controversy Mindset in the Arab Islamic State (p. 236). Beirut: Dar Al-Rayes.

Marranci, G. (2009). Understanding Muslim Identity, Rethinking Fundamentalism (pp. $29 \& 53)$.

https://dl.uswr.ac.ir/bitstream/Hannan/130542/1/Gabriele_Marranci_Understanding Muslim_Identity_Rethinking_Fundamentalism_2009.pdf

Moadab, A.-W. (2002). The Illusions of Political Islam, Translated into Arabic by Muhammad Bennis and the Author (p. 16). Beirut: Dar Al-Nahar.

Mufti, M. A. (1996). The Pillars and Guarantees of Islamic Governance (p. 52). Riyadh: Al Rayyan Institution for Printing and Publishing.

Qutb, S. (1979). (maealim fi altariq) Milestones in the Road (pp. 18-19, 6th ed.). Beirut: Dar Al-Shorouk.

Qutb, S. (1991). In the Shadows of the Qur'an, Part Three (p. 1256, 17th ed.). Cairo: Dar Al-Shorouk.

Rustam, M. bin Z. Al-A. (2011). The Modernist Understanding of the Religious Text between the Claims of Disciplined Ijtihad and Unrepentant Renewal. In International Forum "Understanding the Quran and Sunna in the Light of the Sciences and Times of Knowledge of the Times" (p. 18). Algeria: Prince Abdul Qadir University.

Saleh, N. A.-Q. (2006). The Dilemma in Religious Thought between Text and Reality (p. 121). Beirut: Dar Al-Taliah.

Sen Nag, O. (2017). What Is Religious Fundamentalism? World Atlas. https://www.worldatlas.com/articles/what-is-religious-fundamentalism.html

Shafai, M. (1999). The Powers of the State between Constitutional and Islamic Thought (p. 18). Cairo: Al-Mahrousa Research Center.

Shboul, H. A. (2018). Allah's Political Sovereignty, as "Imagined" by Fundamentalists Muslim, and Its Role in Disapproving Secularism in the Arab World. International Journal of Asian History, Culture and Tradition, 5, 8.

http://www.eajournals.org/wp-content/uploads/Allahs-Political-Sovereignty-As-Imagi ned-By-Fundamentalist-Muslims-and-Its-Role-in-Disapproving-Secularism-in-the-Ar ab-World.pdf 
Stimson.org (2016).

https://www.stimson.org/event/politicizing-islam-exploring-means-and-objectives

Tavakoli, J. (2017). Fundamentalist Islam and the Roots of Terrorism. Huff Post. https://www.huffpost.com/entry/fundamentalist-islam-and_b_6138084

Wahba, M. (1995). Fundamentalism and Secularism (p. 28). Cairo: Dar al-Thaqafa.

Yassin, El-S. (1996). Cosmic, Fundamentalist, and Postmodernism: The Critique of Traditional Reason, Part One (p. 326). Cairo: Academic Library.

Zaki, M. S. (n.d.). The Muslim Brotherhood and the Egyptian Society (pp. 132-134). Cairo. 